\title{
PKM Pelatihan Optimasi Pendataan Santri Baru Dengan Framework YII pada Pondok Pesantren Askhabul Kahfi Gunungpati Polaman Kecamatan Mijen Kota Semarang
}

\author{
Sendi Novianto ${ }^{1}$, Indra Gamayanto ${ }^{2}$, Hanny Haryanto ${ }^{3}$ \\ 1,2,3 Universitas Dian Nuswantoro; J1. Imam Bonjol 207 Semarang, (+6224) 3517261 \\ E-mail: ${ }^{1}$ sendi.novianto@dsn.dinus.ac.id, ${ }^{2}$ indra.gamayanto@dsn.dinus.ac.id, \\ ${ }^{3}$ hanny.haryanto@dsn.dinus.ac.id
}

\begin{abstract}
Abstrak
Informasi saat ini berperan sangat penting sekali di berbagai bidang, baik dibidang perbankan, bisnis, maupun di bidang pendidikan. Pondok pesantren Askhabul Kahfi adalah lembaga pendidikan islam. Dalam pendataan para santrinya, pondok ini sudah menggunakan sistem informasi secara online. Tetapi pada penerapan pendataan santri-santri yang ada disana belum dilakukan secara optimal. Hal ini menyebabkan banyaknya data yang redudansi / duplikasi. Selain itu juga, efek dari data redudansi ini menyebabkan tidak updatenya data yang ada, hal ini menyebabkan informasi antara data yang redudansi menjadi tidak sinkron / tidak sama. Dengan terjadinya hal ini tentunya akan menyebabkan kebingungan bagi pihak yang berhubungan, misalnya informasi ukuran jas calon santri bisa berbeda saat pengukuran dan pembuatannya. Dari informasi yang didapatkan, hal ini karena sistem informasi yang dipakai adalah buatan dari pihak ketiga, hal ini menyulitkan mereka untuk mendapatkan data yang diinginkan sehingga, secara tidak langsung mereka mengkombinasikan data yang ada dengan data manual. Dengan adanya pengenalan framework dalam membangun sistem informasi, diharapkan mereka nantinya dapat mengelola dan mengembangkan sistem informasi yang sesuai dengan keinginan mereka sendiri secara mandiri dan tentunya juga menghindari adanya redudansi data. Dalam prakteknya, setelah mereka mengetahui fungsi dari framework dan komponen pendukung lainnya, mereka dengan mudah dapat membuat aplikasi sederhana untuk dikembangkan lebih lanjut ke aplikasi sistem informasi pendataan yang lebih komplek.
\end{abstract}

Kata kunci: Optimasi, Pendataan Santri, Framework YII, Pondok Pesantren

\begin{abstract}
Information plays a very important role in various fields, both in banking, business and education. Askhabul Kahfi Islamic boarding school is an Islamic educational institution. In collecting data on the students, this institution has used an online information system. However, the application of data collection for the students there has not been carried out optimally. This causes a lot of data redundancy / duplication. In addition, the effect of this redundant data causes the existing data not to be updated, this causes the information between the redundant data to be out of sync / not the same. This will certainly cause confusion for the parties concerned, for example, information on the size of the suit of a prospective student can be different when measuring and making. From the information obtained, this is because the information system used is made from a third party, this makes it difficult for them to get the desired data, so they indirectly combine existing data with manual data. With the introduction of a framework in building information systems, it is hoped that they will be able to independently manage and develop information systems according to their own desires and of course also avoid data redundancies. In practice, after they know the function of the framework and other supporting components, they can easily create simple applications to be further developed into more complex data collection information system applications.
\end{abstract}




\section{PENDAHULUAN}

Pondok pesantren hampir sama dengan sekolah pada umumnya. Dimana pada ponpes juga terdapat beberapa pelajaran dasar yang umumnya sekolah diajarkan. Perbedaan yang mendasar adalah pada pelajaran agama[1]. Pada sekolah umum, pelajaran agama yang diajarkan hanya berupa pelajaran dasar. Yaitu seputar tata cara beribadah yang benar. Sedangkan pada pondok pesantren, selain diajarkan pelajaran dasar dari agama islam, mereka juga diajarkan untuk mempelajari membaca kitab-kitab agama islam selain kitab suci Al Quran[2].

Untuk dapat mendukung proses belajar mengajar yang ada di pondok pesantren Askhabul Kahfi tersebut, diperlukan adanya sistem yang dapat mengelola administrasi para santri, baik untuk progres dari proses pembelajaran maupun administrasi tiap santri yang terdaftar[3]. Saat ini sudah terdapat sistem informasi yang mendukung akan hal itu, tetapi sistem yang ada dibangun dari native PHP, dimana semua fungsi dan prosedure masih dilakukan secara dasar. Fungsi dan prosedur program yang dibuat secara dasar inilah yang menyebabkan perkembangan dari aplikasi yang ada berjalan lama dan terkesan lambat. Selain itu juga, dapat menyebabkan adanya kode-kode program yang seharusnya tidak diperlukan ditulis. Tentunya hal ini akan menyebabkan aplikasi menjadi tidak stabil dan bahkan akan menjadi sulit untuk dikembangkan lebih lanjut lagi jika aplikasi tersebut sudah mengandung kode yang kompleks. Hal ini terbukti banyaknya fungsi-fungsi yang tidak berjalan sebagaimana mestinya dikarenakan adanya kebingungan terhadap pengurus IT dikarenakan adanya pergantian oleh pengurus yang baru.

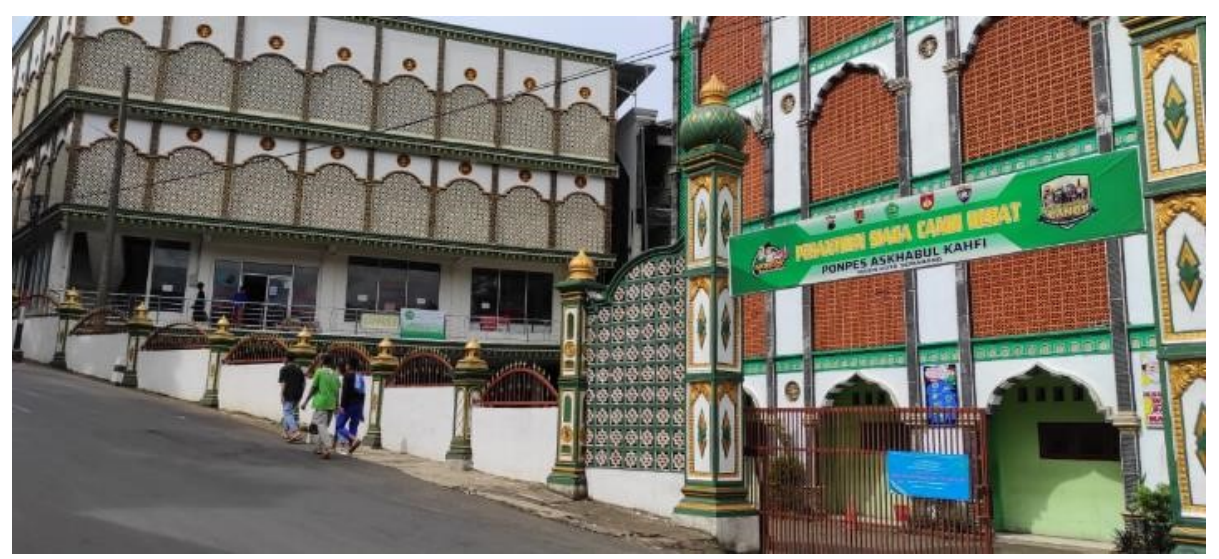

Gambar 1. Pondok pesantren Askhabul Kahfi

PHP merupakan salah satu bahasa pemrograman yang paling sering digunakan oleh orang untuk pembuatan aplikasi berbasis web[4]. Saat ini, banyak sekali framework yang berbasis PHP yang beredar di web secara gratis. Fungsi dari adanya framework ini adalah untuk memberikan kemudahan dalam pembuatan aplikasi berbasis web, sehingga seseorang maupun tim dapat berkolaborasi untuk membangun aplikasi web dari dasar sampai dengan enterprise secara cepat. 


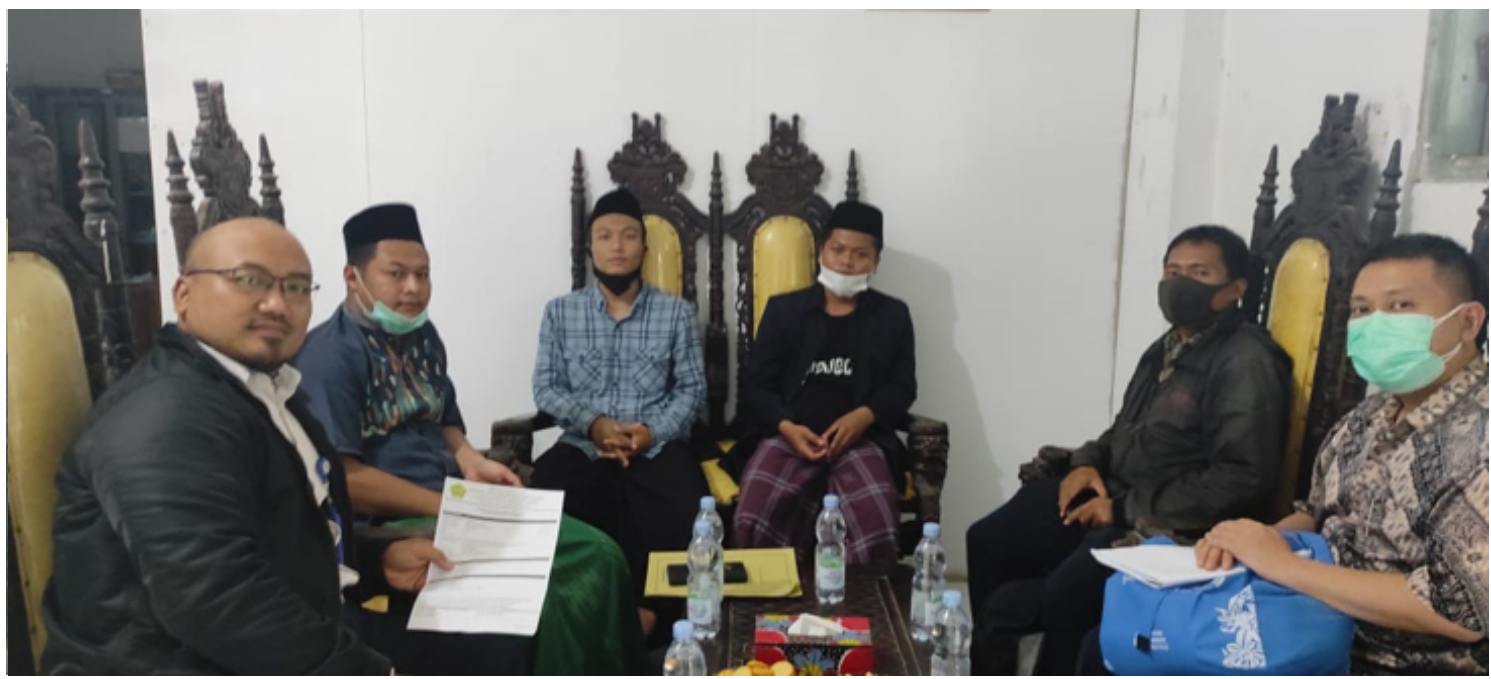

Gambar 2. Koordinasi untuk pelaksanaan PKM

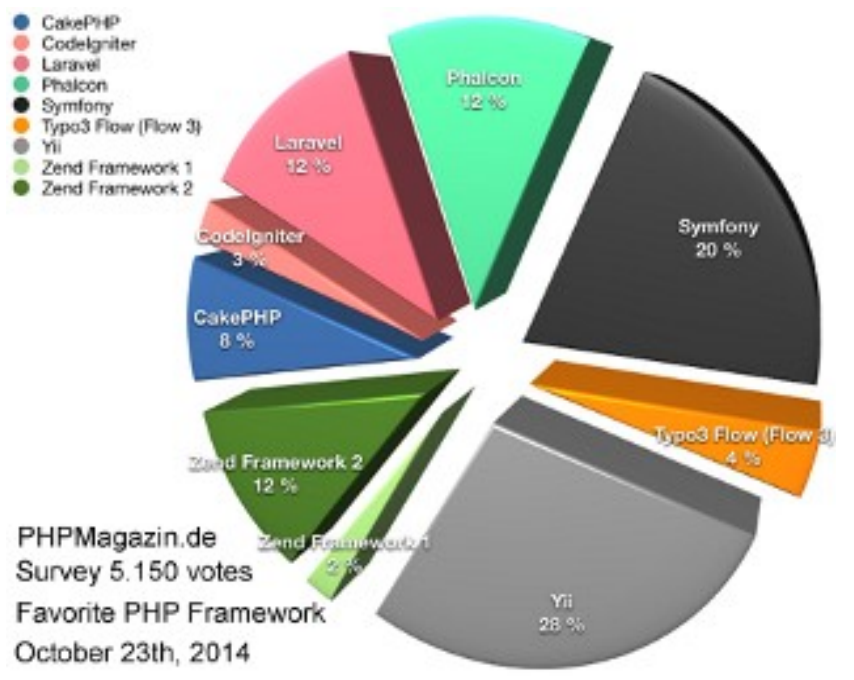

Gambar 3. Tingkat Popularitas YII terhadap Framework PHP lainnya

YII merupakan salah satu framework dari PHP yang dibagun dari komponen-komponen yang sering kali dipakai oleh programer PHP, sehingga nantinya tujuan dari YII sendiri agar para programmer PHP dapat lebih mudah menggunakan komponen yang sering kali dipakai dalam kegiatannya yaitu programming[5]. YII mencoba menyederhanakan beberapa komponen yang sering dipakai dan diformat dengan sedemikian rupa sehingga sesuai dengan pola pemrograman saat ini yaitu OOP. Dari komponen-komponen yang ada tersebut, dipilihlah komponen yang mempunyai kredibilitas yang tinggi dan sering digunakan oleh masyarakat programmer php pada umumnya. Komponen tersebut antara lain adalah Jquery, Bootstrap, SwifMailer, dan banyak komponen pendukung lainnya. Saat ini versi dari YII framework itu sendiri sudah mencapai versi 2.041 saat jurnal ini dibuat. Versi ini diluncurkan tepatnya pada tanggal 4 maret 2021. Banyak sekali perubahan dasar dari YII versi 1 sampai ke YII versi 2. Diantara perubahan yang paling mencolok adalah gaya pemrogramannya, yang tadinya konvensional sekarang berubah ke gaya pemrograman OOP[6]. Saat ini YII sudah mendukung PHP 5.1.0, dimana pada versi ini banyak sekali pengembangan yang dilakukan oleh PHP, dan saat ini juga PHP sudah sampai ke versi 8.0.3 saat jurnal ini dibuat[4]. 
Dalam proses penerimaan santri baru, diperlukan adanya pendataan di awal masuk. Proses pendataan awal ini nantinya akan dipakai terus sampai dengan santri tersebut lulus / pindah dari pondok yang ditempatinya. Pada proses pendataan awal ini juga berkaitan dengan dokumen pendukung dari calon santri. Dokumen pendukung tersebut berupa akte kelahiran, kartu keluarga, serta buku rapot dari pendidikan sebelumnya. Dokumen pendukung ini nantinya akan digunakan untuk verifikasi data yang yang diisikan oleh calon santri tersebut. Dalam proses pendataan tersebut, banyak sekali aplikasi pendukung yang bisa digunakan, pada umumnya mereka akan menggunakan aplikasi dari microsoft ,yaitu microsoft excel. Dengan aplikasi tersebut mereka dapat mengisikan berbagai macam data, mulai dari data nama, alamat, tanggal lahir dan sebagainya[7].

Saat ini askha (Pondok Pesantren Askhabul Kahfi) memakai aplikasi berbasis web yang dibuat oleh pihak ketiga. Permasalahan yang ada, setiap kali ada perubahan dari alur yang ada, pihak askha merasa kesulitan untuk menghubungi pihak ketiga tersebut. Jikalau sudah berhasil dihubungi, pihak ketiga tiga tidak segera melakukan perubahan terhadap program yang ada sesuai dengan perubahan yang dikehendaki oleh askha. Selain itu juga, pengelolaan website yang ada juga kurang maksimal, dikarenakan berita-berita yang ada disana adalah berita yang cukup lama, dan terkesan kurang update, padahal di askha sendiri banyak sekali kegiatan yang bisa di upload ke website tersebut dan bisa juga sebagai media promosi yang efektif terhadap semua kegiatan-kegiatan dalam lingkungan askha itu sendiri.

\section{METODE PELAKSANAAN}

Metode pelaksanaan dari kegiatan ini adalah dengan melakukan pelatihan berupa workshop dimana tutor akan memberikan langkah-langkah dasar kemudian akan langsung diikuti dan dipraktekkan oleh peserta. Secara detail, pelaksanaan kegiatan pengabdian ini terdiri dari beberapa tahap. Berikut merupakan tahapan-tahapan yang dilakukan:

1. Melakukan koordinasi dengan pihak pengurus Pondok Pesantren Askhabul Kahfi. Dilakukan untuk memastikan daftar peserta yang akan mengikuti program pelatihan.

2. Menentukan dan membuat detail materi yang akan diberikan.

3. Menentukan waktu dan tempat penyelenggaraan pelatihan. Waktu disesuaikan dengan waktu luang peserta dan pemateri.

4. Membuat undangan bagi mitra. Undangan diberikan pada peserta untuk informasi waktu, tempat dan agenda pelatihan.

5. Menyiapkan sarana dan prasarana kegiatan, lab komputer, laptop, desktop dan proyektor. Hal ini dilakukan agar pelaksaan kegiatan dapat berlangsung dengan baik dan lancar.

6. Pelaksanaan tutorial dan praktek yang dilakukan langsung di tempat. Tutorial yang diberikan akan langsung dipraktekkan oleh peserta.

7. Adanya bimbingan dan konsultasi yang dilakukan untuk membantu peserta yang mengalami kesulitan.

8. Melakukan pengarsipan dan dokumentasi. Administrasi yang meliputi undangan peserta, surat menyurat, dokumentasi foto, dan daftar hadir diarsipkan dan untuk pembuatan laporan.

9. Membuat laporan. Hal ini dilakukan guna memberikan laporan kepada instansi bahwa kegiatan yang dilakukan benar-benar dilakukan.

10. Menyiapkan tim pendamping untuk monitoring. Hal ini digunakan untuk memantau perkembangan dan ketrampilan hasil pelatihan. 


\section{HASIL DAN PEMBAHASAN}

Workshop ini dilakukan pada hari minggu tanggal 28 Maret 2021 pada pukul 9 pagi. Pada kegiatan awal, kita memperkenalkan kenapa kita perlu berkenalan dengan framework dalam pemrograman web khususnya PHP. Dari perkenalan framework ini, kita memperkenalkan berbagai macam framework seperti CakePHP, CodeIgniter, Laravel, Symfony, Yii dan lainnya. Dari beberapa framework yang kami kenalkan itu, kami membahas lebih detail mengenai framework YII. Dari tahap pengenalan framework ini kita juga menjelaskan mengenai alasan-alasan kenapa kita harus memakai framework dalam pengembangan suatu sistem.

Dalam kegiatan programming baik di lingkungan desktop maupun lingkungan web, kita tidak lepas dari yang namanya pembuatan fungsi dan prosedur. Hal ini dilakukan tentunya untuk mempermudah menyingkat beberapa perintah dalam programming ke dalam perintah yang lebih singkat dan mudah untuk diingat. Pada umumnya, pembuatan fungsi dan prosedure itu dilakukan secara manual, dimana kita harus mengetikkan beberapa kode program yang di jadikan satu paket, sehingga nantinya dalam penggunaannya cukup dengan memanggil nama alias yang kita buat. Dengan nama alias yang kita berikan, proses eksekusi dari kumpulan baris program itu dapat berjalan dengan cepat dan kita tidak memerlupan mengetik ulang kembali kode-kode program tersebut[8][9].

Dalam pembuatan fungsi dan prosedure secara manual, pastinya tidak lepas juga dari adanya bug ataupun kesalahan perintah lainnya. Jika hal ini terjadi tentunya, kita harus menemukan dan membenarkan kode-kode yang salah tersebut. Kejadian seperti ini tentunya juga akan memakan waktu yang cukup lama, dan juga menghambat pekerjaan yang lain.

Dari hal tersebut, kami lalu bandingkan dengan pemakaian framework, baik dalam segi lingkungan desktop maupun lingkungan web. Dalam pemakaian framework terlihat sekali proses pembuatan aplikasi menjadi lebih cepat, efektif serta efisien. Bukan hanya itu saja, dengan memakai framework juga membantu para developer dalam perencanaan, pembuatan dan pemeliharaan suatu aplikasi, sehingga aplikasi yang dibangun selalu dapat terpantau serta terdokumentasi secara tidak langsung. Dengan adanya struktur dari framework itu sendiri juga dapat menghasilkan aplikasi yang jauh lebih stabil dan handal hal ini dikarenakan framework sudah melalui proses uji baik itu stabilitas dan juga kehandalannya saat di proses.

Selain itu juga, dengan adanya framework dapat juga meningkatkan keamanan dari data-data yang akan diproses serta adanya antisipasi cela-cela keamanan yang mungkin timbul. Hal ini dikarenakan framework yang sudah dinyatakan stabil oleh pembuatnya tentunya sudah melalui proses yang panjang untuk di tes di berbagai kondisi yang ada, dimana hal ini mungkin tidak akan pernah kita dapatkan ketika kita membuat program tanpa memakai framework.

Dari penjelasan mengenai dasar kenapa kita menggunakan framework yang disertai alasan serta maksud dan tujuannya, kami melanjutkan untuk memperkenalkan framework YII. Pengenalan ini dimulai dari cara instalasi framework tersebut. Sebelum menginstall framework YII, terlebih dahulu komputer yang akan dipakai diwajibkan menginstall php server dan juga database MySql karena ini adalah hal dasar yang wajib ada sebelum kita memakai framework YII untuk membuat aplikasi.

Setelah semua aplikasi pendukung berupa PHP server dan juga database MySql terinstall ke dalam komputer yang akan dipakai oleh framework YII tersebut, kami lanjutkan dengan pengenalan composer. Composer disini berfungsi untuk mempermudah instalasi langsung dari server YII, sehingga kedepan jika ingin menginstall framework YII akan selalu mendapatkan framework YII yang terbaru tentunya langsung dari server pusatnya di internet. Selain itu juga, composer berguna juga untuk menginstall modul pendukung lain selain modul inti dari framework YII. Contoh-contoh modul pendukung lainnya berupa komponen tanggal yang dilengkapi dengan waktu sampai dengan jam, menit dan detik, komponen field text yang hanya bisa diisi dengan angka saja untuk isian nilai angka, dan masih banyak lagi komponen pendukung lain untuk menunjang aplikasi nantinya bisa lebih interaktif terhadap usernya. 


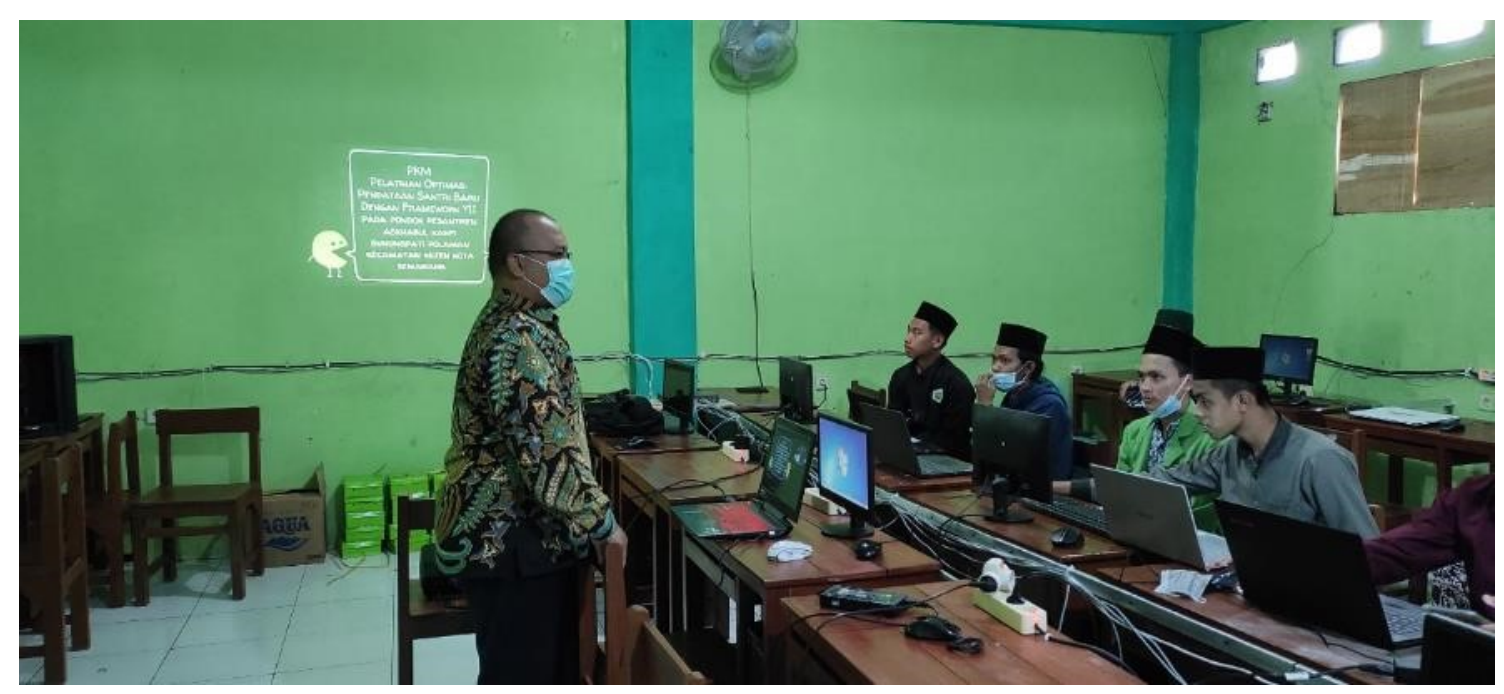

Gambar 4. Pembukaan acara pengabdian

Setelah semua peserta berhasil menginstall framework YII, kita lanjutkan ke cara seting awal dari pemakaian framework YII tersebut. Untuk framework YII ini terdapat dua pilihan aplikasi, yaitu basic aplikasi dan advanced aplikasi. Perbedaan dari kedua aplikasi tersebut terletak di fungsinya, dimana basic aplikasi diperuntukkan untuk aplikasi yang tidak membutuhkan login user, jadi hanya untuk admin saja, atau sebaliknya, aplikasi yang tidak membutuhkan login admin, jadi hanya untuk kebutuhan login user saja. Sedangkan advanced model pada framework YII ini diperuntukkan untuk enterprise aplikasi, dimana butuh adanya frontend dan backend aplikasi, sehingga login untuk user maupun admin diperlukan.

Untuk mempermudah dua login yang dalam satu aplikasi web tersebut, dibutuhkan setingan khusus agar halaman login user serta halaman login admin tidak tercampur. Framework YII menyediakan fasilitas ini, sehingga nantinya user biasa yang tidak mengetahui halaman login admin pun tidak akan bisa mengakses halaman tersebut dengan mudah. Selain itu juga, kita bisa juga memberikan batasan IP mana saja yang boleh mengakses halaman admin, tentunya hal ini bisa menjadi nilai tambah untuk keamanan di internet nantinya ketika kita sudah upload aplikasi ini menuju online. 

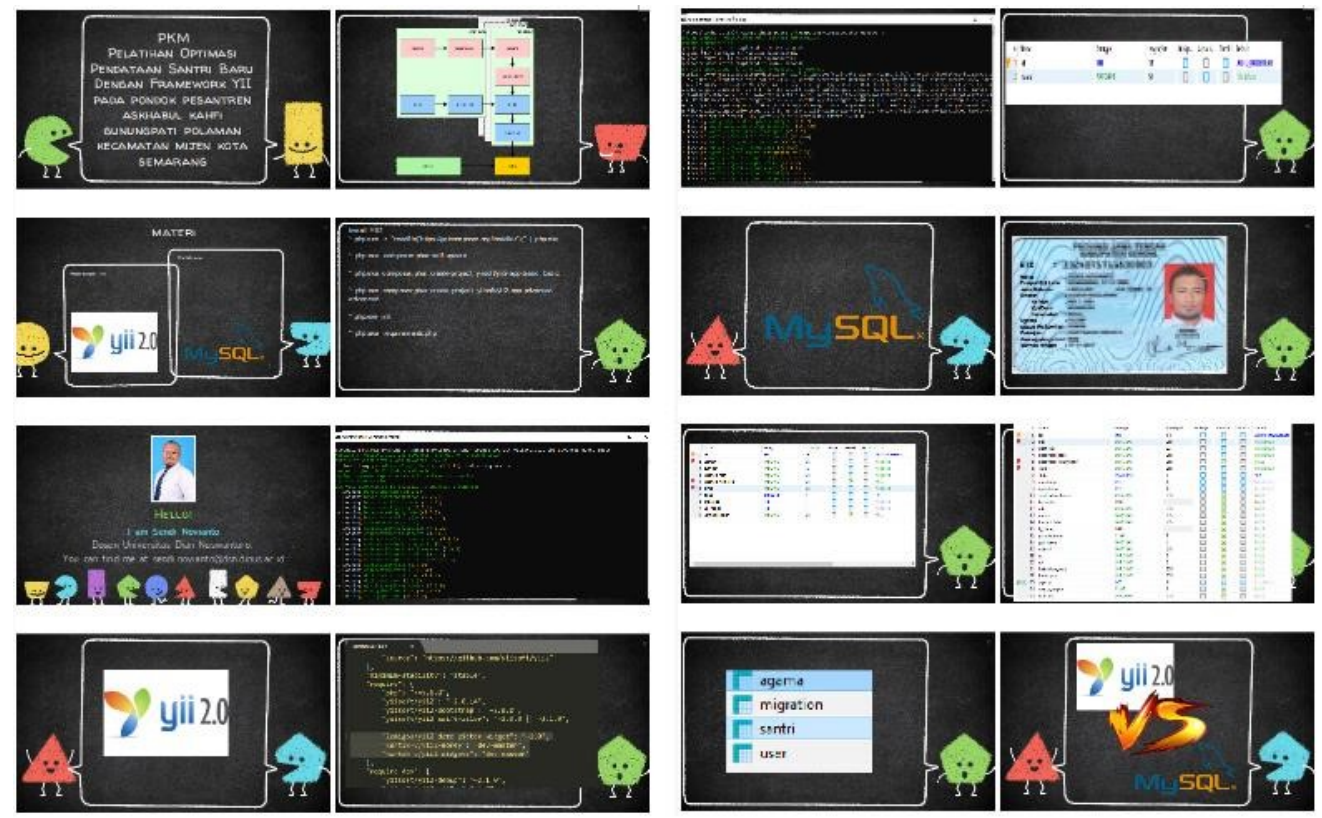

Gambar 5. Slide Presentasi

Setelah setingan dasar selesai kita ajarkan, langkah berikutnya adalah menghubungkan framework YII dengan database yang akan kita pakai untuk menyimpan data yang dimasukkan oleh user maupun oleh admin. Untuk mengatur koneksi kedatabase pun tergolong cukup mudah, yaitu tinggal mengganti setting file yang ada di folder commonlconfiglmain-local.php. pada lokasi tersebut, kita tinggal memasukkan ip dari database kita disertai dengan user dan password untuk administrator database kita.

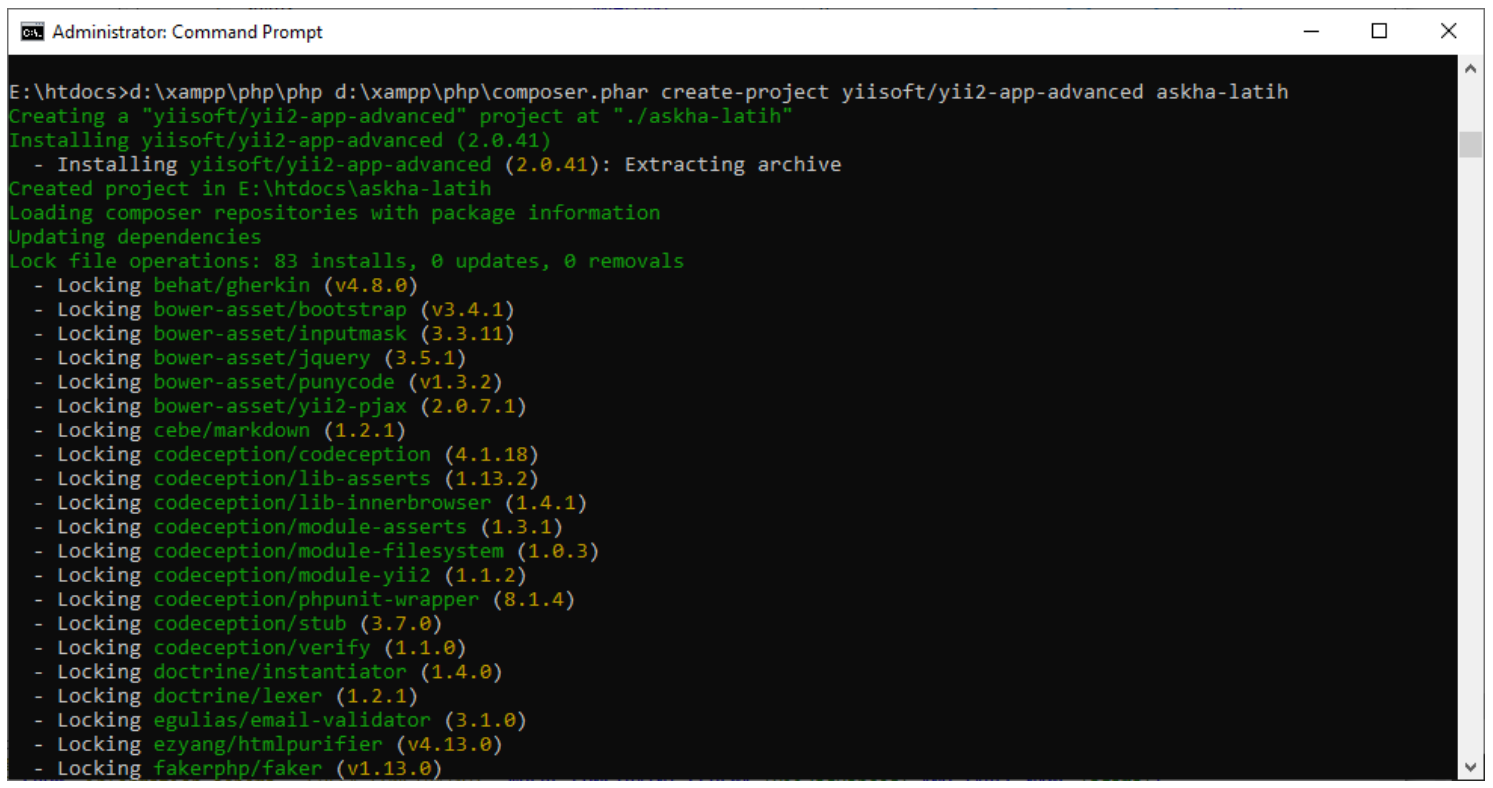

Gambar 6. Proses Instalasi YII Framework 

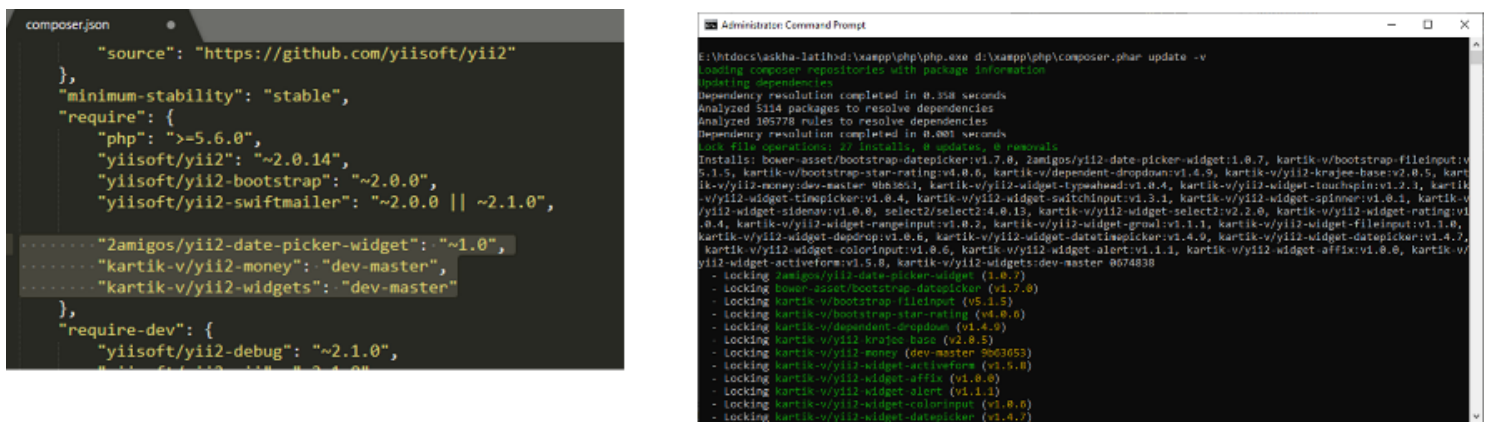

Gambar 7. Proses Instalasi Plugin pada YII Framework

Setelah koneksi database sudah disiapkan, langkah berikutnya pada workshop ini adalah membuat fitur CRUD (Create , Update, Delete)[10], dimana fitur ini adalah fitur wajib dalam sebuah apliksi untuk administrasi pengelolaan data pada database nantinya. Untuk pembuatan CRUD disini, framework YII memiliki kelebihan yaitu dengan fitur GUI untuk CRUD, fitur ini dinamakan GII. Dengan fitur ini, programmer tinggal memasukkan nama tabel yang akan dibuatkan CRUD oleh GII, kemudian secara otomatis, CRUD untuk tabel yang dimaksudkan akan terbentuk dengan sendirinya, sehingga programmer hanya tinggal memoles tampilan yang akan di tampilkan saja. Dengan adanya fitur GII ini tentunya dapat menghemat waktu yang diperlukan programmer dibandingkan dengan pembuatan CRUD secara manual untuk tiap tabelnya.

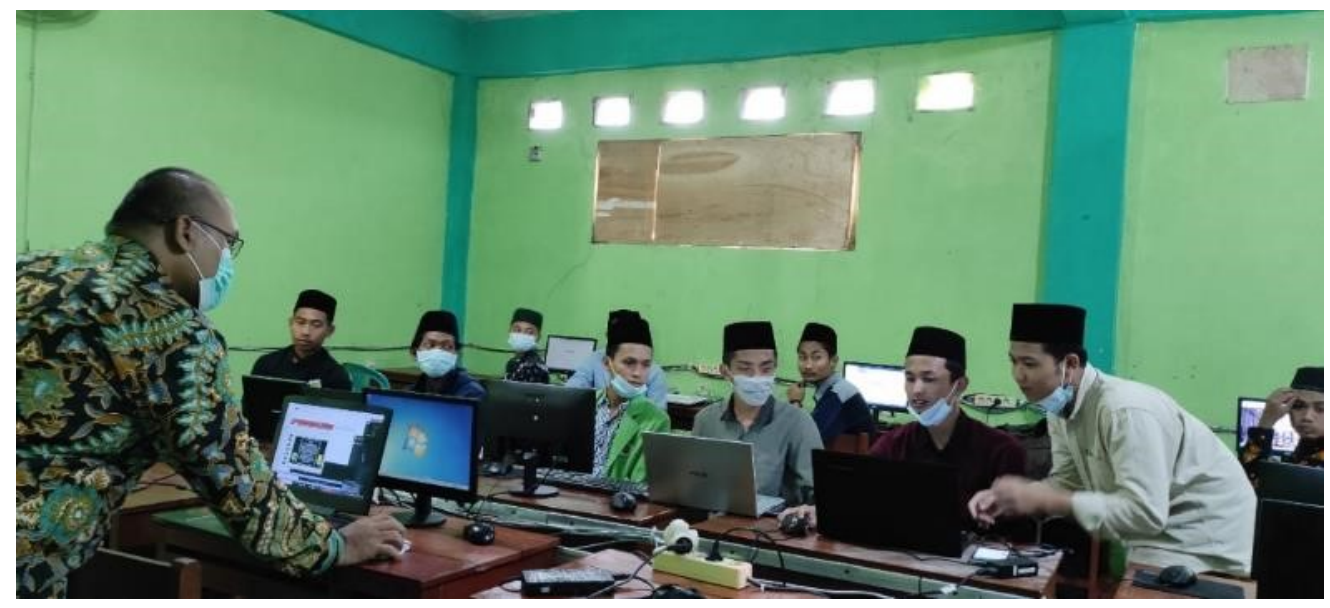

Gambar 8. Suasana Pelaksanaan Praktek

Dalam pelaksanaan pembuatan CRUD, framework YII juga mendukung pembuatan virtual tabel, dimana tabel secara fisik tidak terdapat dalam database, tetapi kita bisa mengaksesnya. Tabel ini biasanya dibentuk dikarenakan tidak diperlukannya penambahan ataupun update dari data tabel tersebut. Sebagai contohnya tabel yang akan dibuat secara virtual adalah tabel jenis kelamin serta tabel agama. Dimana untuk tabel jenis kelamin sudah dipastikan ada 2 jenis data saja, yaitu wanita dan pria. Sedangkan tabel agama saat ini juga hanya terdapat 6 agama nasional yang diakui oleh pemerintah yaitu mulai dari agama Islam, Kristren Protestan, Katholik, Hindu, Budha, Konghuchu. Bisa dipastikan semua data dalam virtual tabel itu dalam waktu yang lama tidak diperlukan adanya update sehingga perlu dibuat tabel virtual, hal ini juga untuk mempercepat akses ke dalam data yang berhubungan.

Untuk tingkatan selanjutnya setelah CRUD, workshop dilanjutkan ke materi HTML dasar, dimana kita mulai menyeting kolom apa saja yang bisa dilihat oleh user, dan kolom mana 
saja dari tabel yang tidak boleh dilihat oleh user. Hal ini bertujuan untuk mempermudah user dalam membaca infomasi yang ditampilkan dan juga untuk keamanan sistem tentunya. Dari persiapan data apa saja yang boleh dilihat dan data yang tidak boleh dilihat, kami lalu melanjutkan kedalam pengkodean ke bahasa HTML dan CSS untuk memperindah tampilan agar user bisa lebih mudah membaca informasi didalamnya[11].

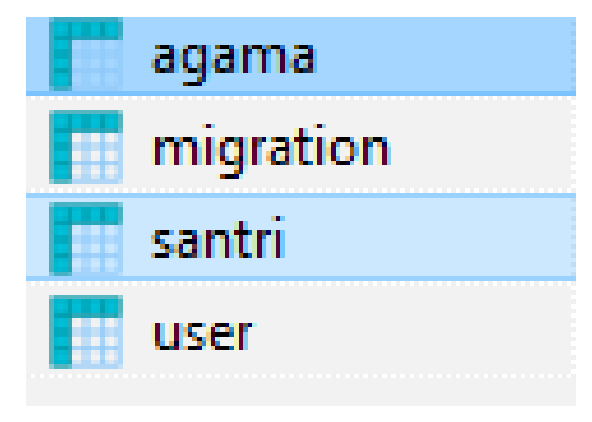

Gambar 9. Tabel yang akan dipakai

Selain mengkode dalam bahasa HTML, kami juga menata kembali letak menu yang ada pada tiap frontend maupun backend. Tampilan menu yang ada juga bisa kita kustom sesuai dengan siapa yang login. Hal ini bisa dilakukan dengan menggunakan fungsi access control filter yang ada pada framework YII, kita tinggal mendefinisikan user dengan id berapa saja yang boleh mengakses menu tertentu, maka secara otomatis, jika ada user yang mau mengakses menu dimana user tersebut tidak memiliki hak untuk akses, maka user tersebut akan diredirect ke halaman informasi yang menyatakan bahwa halaman yang anda akses tidak ada / anda tidak memiliki hak akses pada halaman tersebut.

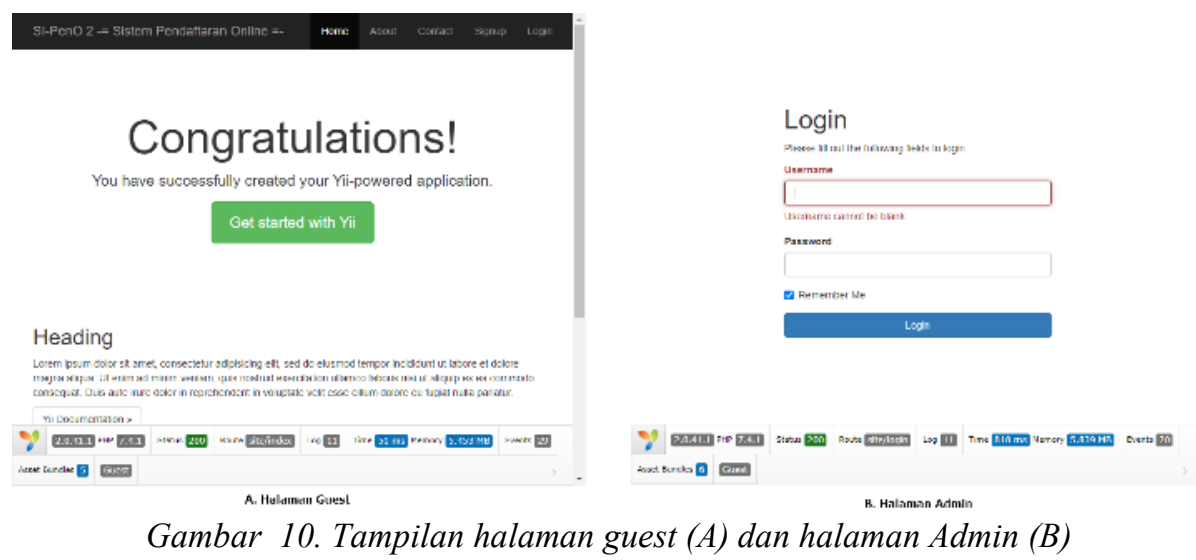

Setelah semua halaman disesuaikan dengan data dan mennu yang akan ditampilkan. Berikutnya adalah setingan untuk pengiriman email. Dalam framework YII kita juga dipermudah untuk pengiriman email. Seting email ada di bagian common $\backslash$ config $\backslash$ main-local.php dibagian mailer. Disana kita hanya mengubar properti dari useFileTransport menjadi false dari semua adalah true. Selain itu, pada sub property transport perlu ditambahkan metode yang akan digunakan, apakah memakai SMPT atau yang lain. Tidak lupa juga untuk memasukkan identitas untuk koneksi ke server email yang akan kita tuju, koneksinya berupa nama host nya serta user dan password untuk koneksi tersebut. Ketika semua sudah disesuaikan, maka framework YII sudah siap untuk dapat melakukan pengiriman email ke manapun. 

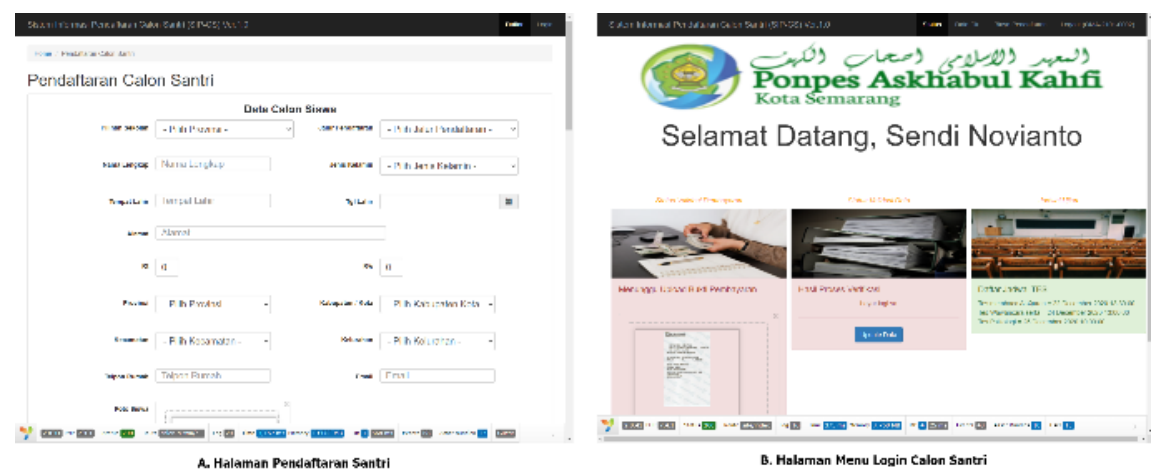

Gambar 11. Hasil Halaman Pendaftaran (A) \& Halaman Menu Calon Santri (B)

Dari awal workshop sampai dengan akhir dari workshop ini, para peserta begitu antusias dalam mengikuti tiap sesinya. Selain itu juga mereka merasakan adanya kepraktisan dalam menggunakan framework, yang semula semua dilakukan secara manual, sekarang sudah menjadi otomatis. Hal ini tentunya berdampak pada meningkatnya kinerja dari para staff IT, dimana waktu untuk mendeploy aplikasi web akan dapat dilakukan secara cepat, efektif dan aman tentunya.

Workshop PKM ini diakhiri pada pukul 11.30 yang kemudian dilanjutkan dengan sesi makan siang serta istirahat sholat. Setelah makan siang selesai, kami berkesempatan untuk mengabadikan moment kebersamaan kami bersama. Dalam workshop ini juga nantinya para peserta akan mendapatkan sertifikat sebagai bukti keikutsertaan mereka dalam workshop PKM ini.

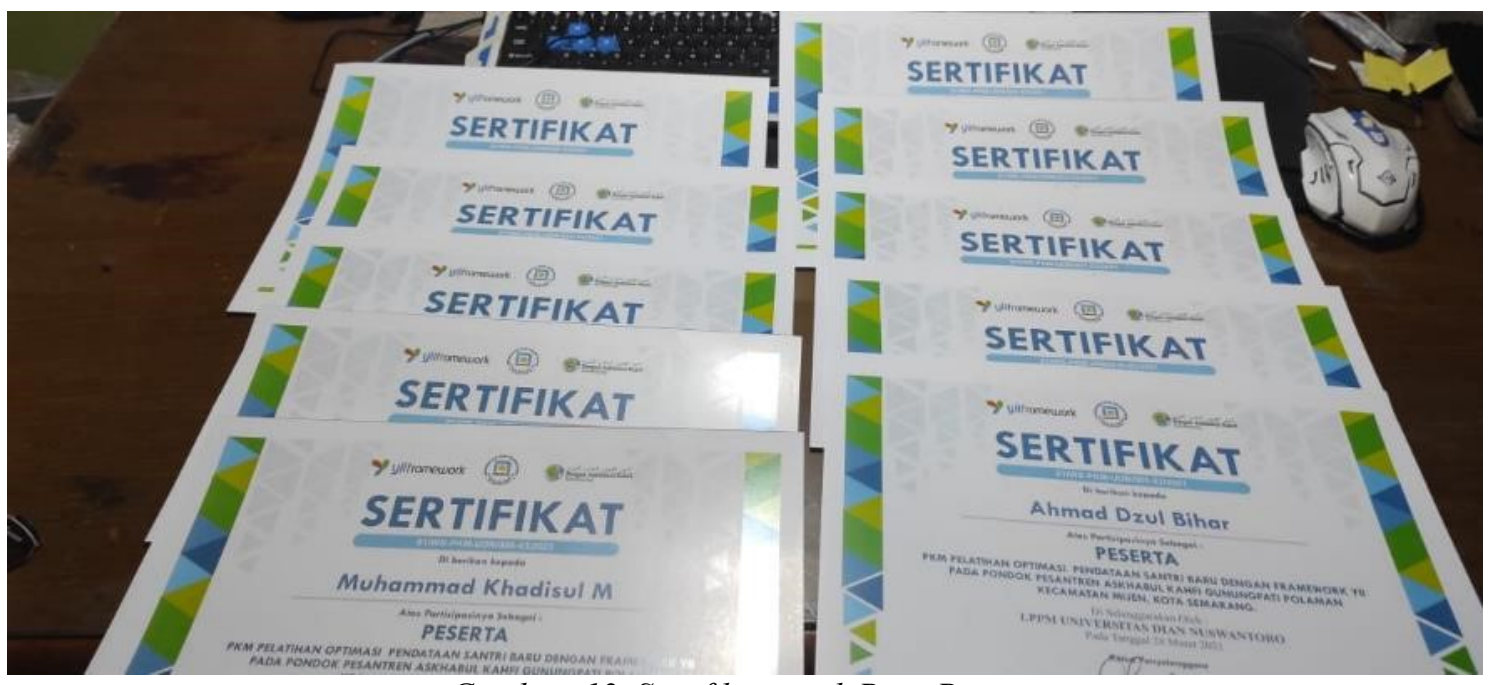

Gambar 12. Sertifikat untuk Para Peserta
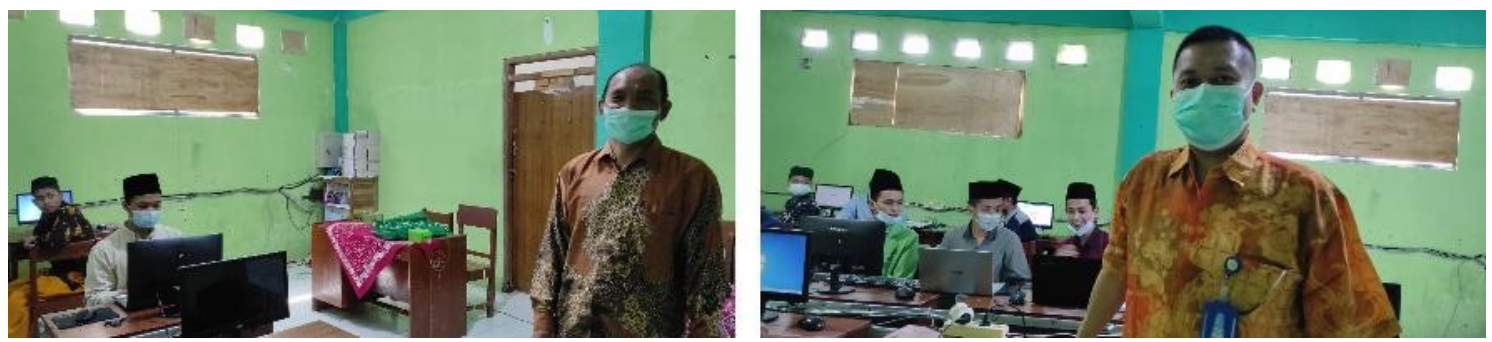


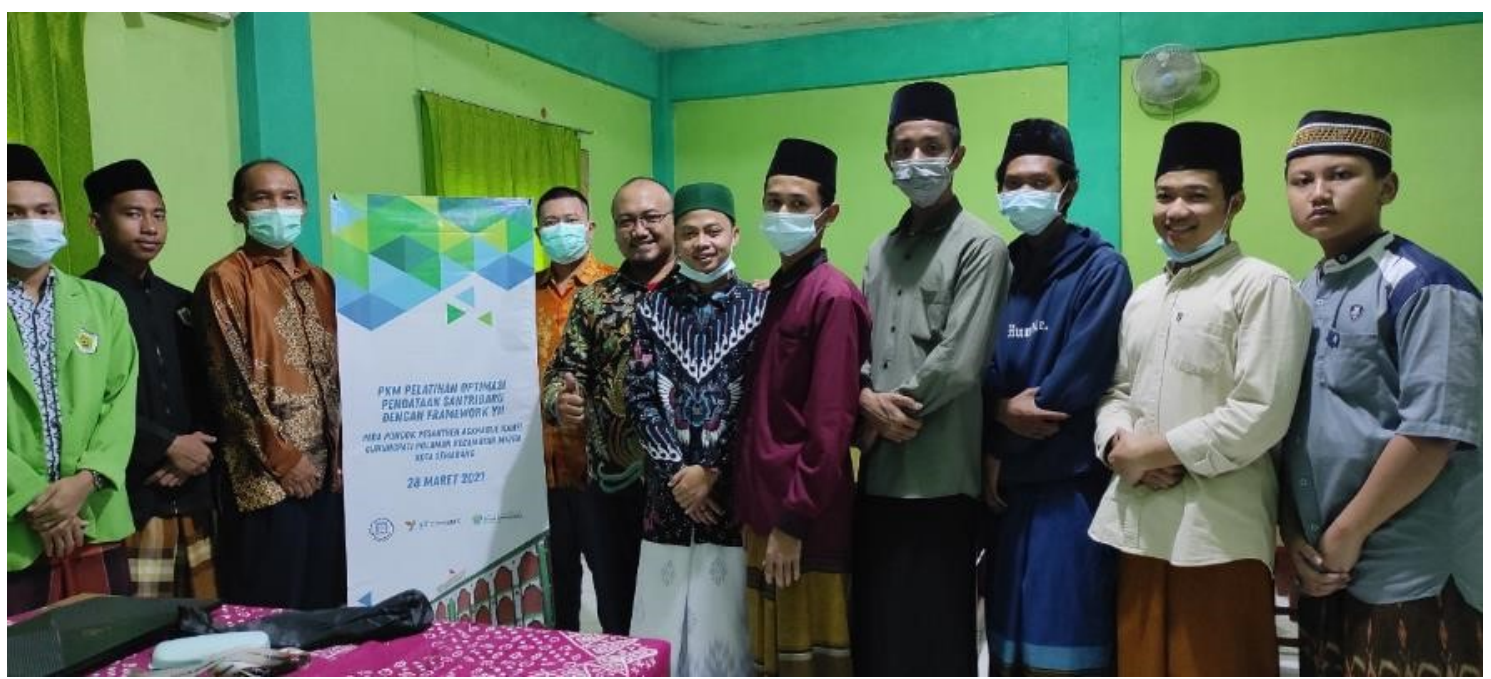

Gambar 14. Foto Bersama Setelah Menyelesaikan Praktek

\section{KESIMPULAN DAN SARAN}

Hasil dari pelatihan ini, para peserta yaitu panitia pendaftaran dan staff IT dari pondok pesantren Askhabul Kahfi kota semarang merasakan manfaat dari mempelajari framework php, dimana sebelumnya para staf disana selalu membuat program untuk keperluan administrasi di pondok dengan menggunakan natif PHP. Dimana hal ini memakan waktu lama untuk membuat input dan output dari suatu proses. Setelah para peserta mengetahui kelebihan dari framework php yang kita ajarkan, mereka merasa bahwa nantinya pekerjaan mereka untuk membuat program dari php akan menjadi lebih mudah dan cepat dalam pengerjaannya. Selain itu juga, mereka merasakan dengan menggunakan framework php ini, program mereka akan menjadi lebih terstruktur, sehingga untuk pengembangan dari program yang menggunakan framework tentunya akan menjadi lebih mudah walaupun di pegang oleh staf baru nantinya.

\section{UCAPAN TERIMA KASIH}

Pengabdian ini dapat terlaksana berkat adanya bantuan dana dari LP2M Universitas Dian Nuswantoro Semarang. Oleh karena itu, melalui abdimas ini kami mengucapkan banyak terima kasih kepada LP2M Universitas Dian Nusawantoro Semarang, selain itu kami juga mengucapkan terima kasih kepada Team Pengabdi serta semua pihak di Pondok Pesantren Askhabul Kahfi kota Semarang dan juga Asisten mahasiswa TI Universitas Dian Nuswantoro Semarang yang telah meluangkan waktunya untuk bisa membantu kami dalam proses pengabdian.

\section{DAFTAR PUSTAKA}

[1] Rodliyah; and S. H, "Manajemen Pondok Pesantren Berbasis Pendidikan Karakter (Studi Kasus di Pondok Pesantren 'Annurryah' Kaliwining Kecamatan Rambipuji Kabupaten Jember)," Cendekia, vol. 12, no. 2, 2014.

[2] Nuryana, Konsistensi Pendidikan Karakter di Pondok Pesantren Al-Ma'un Desa Kepuh 
Palimanan Cirebon. 2013.

[3] Purwanti, "Implementasi Pengembangan Karakter Dalam Pembelajaran Di Lembaga Pendidikan Tinggi Kependidikan (LPTK)," J. Pendidik. Sosiol. Dan Hum., vol. 3, no. 2, pp. 120-131, 2012.

[4] "Best Web Development Languages in 2020." https://www.designveloper.com/blog/web-development-languages-2020/.

[5] "Framework Benchmarks." https://www.techempower.com/benchmarks/.

[6] “Apa itu Yii.” https://www.yiiframework.com/doc/guide/1.1/id/quickstart.what-is-yii (accessed Mar. 31, 2021).

[7] A. S. Zain;, E. M. Sari;, and M. Arif;, "Pengembangan Sistem Informasi Penerimaan Siswa baru berbasis Web Di SMA 1 Annuqayah Sumenep," J. Ilm. Edutic, vol. 4, no. 2, pp. 53-62, 2018.

[8] Sarwindah, "Sistem Pendaftaran Siswa Baru Pada SMP Negeri 1 Kelapa Berbasis Web," SISFOKOM, pp. 110-115, 2018.

[9] Sarwindah, "Perancangan Sistem Informasi Tata Tertib Siswa Pada SMP Negeri 4 Kelapa Berbasis Desktop," J. Untan, 2014.

[10] N. Bunafit, Dasar Pemrograman Web PHP - MySQL Dengan Dreamweaver. Yogyakarta: GavaMedia, 2013.

[11] J. A. Pribadi; and F. Y. Irsyadi; "Sistem Informasi Pendaftaran Siswa Baru Berbasis Web (Studi Kasus : SMA Negeri 1 Pacitan)," PMB, 2015. 